\title{
A COMPARATIVE ASSESSMENT OF ALFATHESIN FOR USE IN OUTPATIENT ANAESTHESIA
}

\author{
G.L. Dunn, P.J. Houlton, D.H. Morison, and R. Rajagopalan
}

\begin{abstract}
Alfathesin is an intravenous anaesthetic agent recently released for use in Canada. It is a mixture of two steroids, alphaxolone $9 \mathrm{mg}$ and atphadolone $3 \mathrm{mg}$ pèr $\mathrm{ml}$ dissolved in cremophor EL $200 \mathrm{mg}$. For this reason, it is usual to express the dose of alfathesin in terms of volume, e.g. $\mu$ l. Alfathesin has been found to be an effective in travenous induction agent ${ }^{1,2,3,4}$ without analgesic properties. ${ }^{5}$

The present study compares alfathesin, fentanyl and nitrous oxide anaesthesia with thiopentone, fentanyl and nitrous oxide in outpatients presenting for minor gy naecological surgery. The objective of this study was to compare the two techniques in terms of cardiorespiratory variables, clinical efficacy, recovery times and patient acceptability.
\end{abstract}

\section{Methods}

Patients. Fifty-four female patients (A.S.A. status I), undergoing aspiration and curettage for therapeutic abortion, were studied. Informed consent was obtained from all patients. No premedication was used. The patients were randomly allocated to one of the two anaesthetic techniques in a double blind manner.

Group I. Anaesthesia was induced with fentanyl $1 \mu \mathrm{g} / \mathrm{kg}$ followed by thiopentone $5 \mathrm{mg} / \mathrm{kg}$ administered into an intravenous infusion over a period of 30 seconds. Anaesthesia was maintained with a thiopentone infusion of 0.2 $\mathrm{mg} / \mathrm{kg} / \mathrm{min}$ commencing immediately after induction, with 70 per cent nitrous oxide in oxygen administered by face mask from a circle system with an absorber.

Group II. Patients were anaesthetized using a technique identical to Group I, except that alfathesin was substituted for thiopentone in a dose of $75 \mu \mathrm{l} / \mathrm{kg}$ for induction and $3 \mu \mathrm{l} / \mathrm{kg} / \mathrm{min}$ for maintenance.

G.L. Dunn, M.B., B.S.,F.F.A.R.C.S., F.R.C.P.(C). P.J. Houlton, M.B., B.S. D.H. Morison, M. B., B.Ch., F.R.C.P.(C). R. Rajagopalan, M.D., F.R.C.P.(C) Department of Anaesthesia, McMaster University, 1200 Main Street West, Hamilton, Ontario, Canada, L8S 459 .
All patients breathed spontaneously and no patient received any vagolytic agent. Additional increments of either thiopentone $50 \mathrm{mg}$ (Group I) or alfathesin $75 \mu \mathrm{l}$ (Group II) were administered if anaesthesia was deemed to be too "light". This was defined as movement in response to a surgical stimulus. In order to ensure the "blind" status of the observer, equivolumetric doses of both thiopentone and alfathesin were prepared as follows: (1) thiopentone 2.5 per cent solution; and (2) alfathesin, $6 \mathrm{ml}$ diluted in saline, to a total volume of $16 \mathrm{ml}$. These drugs were administered in disguised syringes.

\section{Measurements}

The following physiological variables were measured and recorded, prior to and during anaesthesia:

Systolic blood pressure was measured by radial artery palpation at one-minute intervals for the first six minutes and thereafter at two-minute intervals using a standard adult sphygmomanometer cuff.

EKG and pulse rate were continuously displayed by a Hewlett Packard oscilloscope (\#1308A) with digital read-out (\#5601B).

Tidal volume and respiratory rate were measured continuously using a Wright electronic respiration monitor.

End-tidal carbon dioxide (Beckman LB2 rapid $\mathrm{CO}_{2}$ analyser) was continuously sampled through a 16-gauge plastic cannula placed inside the face mask.

The latter three measurements were recorded on a Hewlett Packard paper recorder (HP series $\# 7700$ ). Respiratory minute volume was calculated by adding tidal volume measurements for each minute during the period of study.

Recovery times were recorded, commencing from the termination of anaesthesia:

(a) Open eyes, was defined as the time until the patient first opened her eyes spontaneously.

(b) Orientation time was defined as the time until the patient was orientated in place and time and was estimated at one-minute intervals.

(c) Sit-up time was when the patient was first 
TABLE I

Summary of Patients With Mean Values \pm S.D.

\begin{tabular}{lcccc}
\hline \multicolumn{1}{c}{ Group } & Number & Age (yrs) & Weight (kg) & Anaesthetic time (min) \\
\hline I Thiopentone & 30 & $22.2 \pm 3.6$ & $56.9 \pm 6.0$ & $9.4 \pm 3.0$ \\
Il Alfathesin & 24 & $23.0 \pm 3.5$ & $58.6 \pm 6.0$ & $8.4 \pm 3.3$ \\
\hline
\end{tabular}

TABLE II

Actual Doses of Drugs Employed

\begin{tabular}{lccccc}
\hline \multicolumn{1}{c}{ Group } & $\begin{array}{c}\text { Mean } \\
\text { induction } \\
\text { dose }\end{array}$ & $\begin{array}{c}\text { Mean } \\
\text { infusion } \\
\text { dose }\end{array}$ & $\begin{array}{c}\text { Patients } \\
\text { requiring } \\
\text { supplementary } \\
\text { doses }\end{array}$ & $\begin{array}{c}\text { Mean } \\
\text { supple- } \\
\text { mentary } \\
\text { dose }\end{array}$ & $\begin{array}{c}\text { Mean } \\
\text { total } \\
\text { dose }\end{array}$ \\
\hline I Thiopentone & $5 \mathrm{mg} / \mathrm{kg}$ & $\begin{array}{c}0.175 \mathrm{mg} / \mathrm{kg} / \mathrm{min} \\
\text { II Alfathesin }\end{array}$ & $\begin{array}{c}18(60 \%) \\
8\end{array}$ & $1.1 \mathrm{mg} / \mathrm{kg}$ & $7.3 \mathrm{mg} / \mathrm{kg}$ \\
\hline
\end{tabular}

able to sit up unaided and was assessed at oneminute intervals.

All the above measurements and observations were made by an independent observer who was unaware of the anaesthetic agent being used.

All patients completed a questionnaire on the day following operation which was designed to assess the occurrence of dreams during anaesthesia, the incidence of nausea and vomiting after discharge from hospital and the patients' overall assessment of the anaesthetic. In addition, an indication of subjective recovery time was obtained from their answer to the question "How long after surgery did you feel completely recovered from the anaesthetic?"

\section{STATISTICAL ANALYSIS}

Continuous data were analysed using a twotailed Student t-test. Binomial indices were compared by using a Chi-square analysis, with the application of Yates's correction. For the purpose of this study $P<0.05$ was accepted as being significant.

\section{RESULTS}

Table 1 shows that 30 patients received the thiopentone technique and 24 the alfathesin technique. There was no significant difference in mean age, weight or anaesthetic times between the groups.

Table II shows that 60 per cent of patients in the thiopentone group required supplementary doses as compared to 33 per cent in the alfathesin group, but this difference was not statistically significant. The mean total dose of thiopentone was $7.3 \mathrm{mg} / \mathrm{kg}$ and of alfathesin was $104 \mu \mathrm{l} / \mathrm{kg}$.

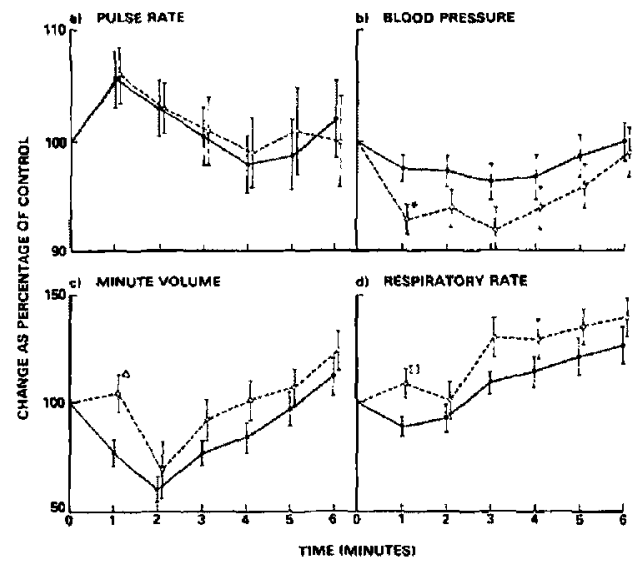

Figure 1 The change in four parameters is shown during the first six minutes after induction of anaesthesia as mean values $\pm 1 S$. E. o----o represents the thiopentone group. represents the alfathesin group. The values do not differ significantly. except where indicated: ${ }^{*} p<.01, \Delta p<.02$, and $a p<.025$.

Physiological variables are shown for the first six minutes after induction of anaesthesia in Figure 1 .

Pulse rate (Figure la) was increased at one minute after induction of anaesthesia but relurned to pre-induction levels by the fourth minute. There was no statistical difference between the groups.

Systolic blood pressure (Figure 1b) decreased slightly in both groups but returned to the preinduction level by the sixth minute. Quantitatively this decrease was greater in the alfathesin group, but was only significant $(P<0.01)$ at the first minute. One patient in each group had a 
TABLE III

Recovery Times as Mean Values \pm S.D.

\begin{tabular}{lcccc}
\hline \hline & Open eyes (min) & Orientation (min) & Sit up (min) & Subjective (hr) \\
\hline I Thiopentone & $8.2 \pm 4.9$ & $10.9 \pm 5.3$ & $15 \pm 9.3$ & $4.54 \pm 5.43$ \\
II Alfathesin & $5.6 \pm 2.6$ & $8.0 \pm 3.0$ & $9.7 \pm 3.0$ & $3.25 \pm 5.14$ \\
& $P<0.05$ & $P<0.02$ & $P<0.01$ & N.S. \\
\hline
\end{tabular}

transient fall in blood pressure to less than 75 per cent of the pre-induction level.

Respiratory minute volume (Figure 1c) decreased in both groups following induction of anaesthesia and reached minimum values at two minutes. Over the next four minutes, minute volume gradually increased to levels slightly above pre-induction values. Although the minute volume in the thiopentone group was lower than in the alfathesin group during the entire period of study, the difference was statistically significant only at the first minute $(\mathrm{P}<0.02)$.

Respiratory rate (Figure 1d) was slightly decreased during the first two minutes of anaesthesia in the thiopentone group compared to little change from the pre-induction level in the alfathesin group. This difference was statistically significant at the first minute $(P<0.025)$. Thereafter, respiratory rates increased steadily in both groups. This increase was more marked in the alfathesin group but the difference was not statistically significant.

End-fidal carbon dioxide did not change significantly during anaesthesia compared with preinduction values in either group.

Recovery times (Table III) were significantly shorter in those patients receiving alfathesin, where the mean sit-up time was 9.7 minutes compared to 15 minutes in the thiopentone group. The subjective recovery time, though slightly longer in the thiopentone group than in the alfathesin group, was not significantly different.

TABLE IV

InGidence of Pre-operative Side Effects

\begin{tabular}{lcc}
\hline \multicolumn{1}{c}{ Side effects } & Thiopentone & Alfathesin \\
\hline Apnoea & 8 & 8 \\
Cough & 1 & 1 \\
Hiccup & 1 & 3 \\
Laryngospasm & 1 & 1 \\
Movements & 17 & 8 \\
Skin rash & 1 & 1 \\
Total patients* & $22(73 \%)$ & $16(67 \%)$ \\
Less movements) & $11(37 \%)$ & $11(46 \%)$ \\
\hline
\end{tabular}

*N.B. Some patients exhibited multiple side effects.
Side effects (Table IV) occurred similarly in both groups, though the incidence of movements during anaesthesia was much higher in the thiopentone group. The overall incidence of side effects was 73 per cent of patients in the thiopentone group and 67 per cent in the alfathesin group. As indicated in Table IV, when movements are excluded, the incidence of other side effects was slightly greater in the alfathesin group at 46 per cent of patients compared with 37 per cent of patients in the thiopentone group, but this difference was not statistically significant.

Post-operative side effects (Table V) occurred with slightly greater frequency in the alfathesin group but was not significantly different from that found in the thiopentone group, either during the first hour (in the recovery room) or between the first and fifth hours post-operatively (in the ward until discharge).

The post-anaesthetic questionnaire (Table VI) had a similar response rate in both groups. In the thiopentone group, 27 per cent of patients experienced dreams during anaesthesia while none occurred in the alfathesin group. The overall incidence of nausea and vomiting was similar in both groups. Approximately 40 per cent of patients in both groups experienced drowsiness on the evening following anaesthesia. The patient acceptance of the anaesthetic technique was higher at 74 per cent in the alfathesin group compared with 58 per cent in the thiopentone group, although this difference was not statistically significant.

\section{Discussion}

In a comparative study of the clinical effectiveness of two drugs, it is important that the ratio of doses be chosen with great care so that equipotency may be achieved. Previous comparative studies ${ }^{3,6,8}$ have utilized potency ratios from $10 \mu \mathrm{l}$ to $15 \mu \mathrm{l}$ of alfathesin per $\mathrm{mg}$ of thiopentone. However, the potency ratio varies with the dosage level employed, since the dose response curves for these two drugs have different slopes. ${ }^{3,9}$ Using $\mathrm{C}^{14}$ labelled alfaxolone, Strunin ${ }^{10}$ has shown a rapid initial plasma clearance occur- 
TABLE $V$

InCidence of Post-operative Side Efrects

\begin{tabular}{llllll}
\hline & \multicolumn{2}{c}{ Thiopentone } & & \multicolumn{2}{c}{ Alfathesin } \\
\cline { 2 - 3 } \cline { 5 - 6 } \multicolumn{1}{c}{ Side effects } & $<1 \mathrm{hr}$ & $1-5 \mathrm{hr}$ & & $<1 \mathrm{hr}$ & $1-5 \mathrm{hr}$ \\
\hline Abdominal cramps & 3 & 1 & 2 & 0 \\
Crying & 1 & 0 & & 2 & 0 \\
Dizziness & 1 & 1 & 1 & 1 \\
Headache & 0 & 0 & & 1 & 0 \\
Nausea & 2 & 3 & & 2 & 3 \\
Vomiting & 2 & 1 & 2 & 3 \\
Total patients & $7(23 \%)$ & $6(20 \%)$ & $8(33 \%)$ & $7(29 \%)$ \\
\hline
\end{tabular}

TABLE VI

POST-ANAESTHETIC QUESTIONNAIRE

\begin{tabular}{|c|c|c|}
\hline & Thiopentone & Alfathesin \\
\hline $\begin{array}{l}\text { Number of patient replies } \\
\text { Incidence of dreams during anaesthesia } \\
\text { After discharge from hospital - Nausea } \\
\begin{aligned} \text { Drowsiness on same evening } \\
\text { Comments regarding anaesthetic - Pomiting } \\
\text { - Positive } \\
- \text { Neutral } \\
\text { - Negative }\end{aligned}\end{array}$ & $\begin{array}{l}26(87 \%) \\
7(27 \%) \\
4(12 \%) \\
0 \\
11(42 \%) \\
15(58 \%) \\
9(34 \%) \\
2(8 \%)\end{array}$ & $\begin{array}{l}19(79 \%) \\
0 \\
2(10 \%) \\
1(5 \%) \\
7(37 \%) \\
14(74 \%) \\
5(26 \%) \\
0\end{array}$ \\
\hline
\end{tabular}

ring within two minutes. When using an infusion technique with a mean anaesthetic time slightly in excess of eight minutes, it would seem reasonable to anticipate less accumulation of alfathesin than of thiopentone, since the latter is metabolized slowly. Thus, in order to ensure near equipotency in terms of dose employed, it was decided that a potency ratio of alfathesin $15 \mu$ l to thiopentone $1 \mathrm{mg}$ would be used.

The anaesthesia employed in Group I was a modification of a standard technique which is commonly used: a thiopentone-fentanyl induction is followed by incremental doses of thiopentone supplemented with nitrous oxide. For the purposes of this study, an infusion of each drug was substituted for the incremental doses, to standardize the anaesthetic and permit unbiased comparison. The use of standardized supplementary doses, given only in response to patient movement, allowed satisfactory anaesthesia to be obtained without compromising the objectivity of the study. This protocol resulted in a high incidence of supplementary doses -60 per cent in the thiopentone group and 33 per cent in the alfathesin group. One can conclude that somewhat higher induction and infusion doses of thiopentone and alfathesin would be necessary to obviate the need for supplementary doses and to make this a clinically acceptable method of administering these drugs. One suspects that the true potency ratio of alfathesin to thiopentone under these conditions is less than $15 \mu \mathrm{l}$ to one $\mathrm{mg}$, despite the fact that the difference in incremental dose requirements was not statistically significant.

From a clinical view point, alfathesin compared well with thiopentone. The effect on measured physiological variables was remarkably similar with both techniques. Alfathesin produced a marginally greater fall in blood pressure, but thiopentone produced more respiratory depression, while there was no difference in pulse rate changes. The incidence of dreaming during operation was greater with thiopentone but no difference was found for other side effects either during or after operation. This significant difference in the incidence of dreams between the two groups is likely due to a greater depth of anaesthesia achieved in the alfathesin group, but it raises the question as to whether alfathesin itself may have some amnesic action. Over-all there was virtually no clinical difference between the two drugs.

The most marked difference was found in the recovery times, which were significantly shorter in the alfathesin group during the initial recovery period and although the same trend was found for the subjective recovery time, this was not statis- 
tically significant. The more rapid recovery after alfathesin suggests that this drug is preferable for outpatient anaesthesia.

\section{SUMMARY}

Alfathesin and thiopentone were compared in a double blind study where each drug was given by intravenous infusion supplemented with fentanyl and nitrous oxide, in 54 healthy female patients under-going therapeutic abortion. The two drugs were similar in terms of changes in cardiorespiratory variables, side effects, clinical efficacy, and patient acceptability. Alfathesin produced a significantly more rapid recovery from anaesthesia, without the high incidence of dreams found with thiopentone in this study. Alfathesin would seem to be the preferable drug for use in outpatients undergoing minor surgical operations.

\section{RÉSUMÉ}

Dans le cadre d'une étude à double insu, 54 patients chez qui l'on procédait à un avortement thérapeutique ont reçu une infusion d'alfathesin, ou une infusion de thiopental supplémentée de protoxyde d'azote et de fentanyl.

Les modifications cardiorespiratoires, les effets secondaires, ainsi que l'efficacité clinique des deux agents ont été jugés similaires.

L'éveil des patientes ayant reçu une perfusion d'alfathesin a cependant été plus rapide et ce de façon significative. Cet agent nous apparaît donc préférable dans les cas de chirurgie ambulatoire.

\section{ACKNOWLEDGEMENTS}

The authors wish to thank their colleagues in the Departments of Anaesthesia and Gynaecology, and the operating room staff at McMaster
University Medical Centre for their co-operation. Special thanks is due to Ms. Sheila Seaman for her assistance in preparation of the manuscript.

This study was supported by a grant-in-aid from Glaxo Laboratories, who also provided supplies of alfathesin.

\section{REFERENCES}

1. Swerdlow, M. Althesin - a new intravenous anaesthetic. Canad. Anaesth. Soc. J. 20: 186 (1973).

2. Savege, T.M., Foley, E.l., Coultas, R.J., Walton, B., Strunin, L., Simpson, B.R., \& ScoTt, D.F. CT 1341: some effects in man. Cardiorespiratory, electroencephalographic and biochemical changes. Anaesthesia 26:402 (1971).

3. Tammisto, T., Takki, S., TigerstedT, 1., \& KAUSTE, A. A comparison of althesin and thiopentone in induction of anaesthesia. Brit. J. Anaesth. 45: $100(1973)$

4. Broadley, J.N. \& Taylor, P.A. An assessment of althesin for the induction of anaesthesia in cardiac surgical patients - a comparison with thiopentone. Brit. J. Anaesth. 46:687 (1974).

5. DuCallar, J. The effects in man of infusions of Althesin with particular regard to the cardiovascular system. Postgrad. Med. J. Suppl. (2) 48:66 (1972).

6. Clarke, R.S.J., Dundee, J.W., \& Carson, I.W. Some aspects of the clinical pharmacology of Althesin. Postgrad. Med. J. Suppl. (2) 48: 62 (1972).

7. Miller, D.C., Bradford, E.M.W. \& CAmpBell, D. Haemodynamic effects of Althesin in poor risk patients. Postgrad. Med. J. Suppl. (2) 48: 133 (1972).

8. ObDRZALEK, J. Althesin and thiopentone: a clinical comparison. Canad. Anaesth. Soc. J. 22: 601 (1975).

9. Davis, B. \& Pearce, D.R. An introduction to Althesin (CT 1341). Postgrad. Med. J. Suppl. (2) 48: 13 (1972)

10. Strunin, L., Strunin, J.M., Knights, K.M., \& WARD, M.E. Metabolism of ${ }^{14} \mathrm{C}$-labelled alphaxolone in man. Brit. J. Anaesth. 49:609 (1977). 